\title{
"LLEGARÁN LOS MALOS DÍAS PARA EL AMOR Y EL OLVIDO": EL ESPACIO DE LA MEMORIA EN MIRAMAR HOTEL DE EGOR MARDONES
}

\author{
"BAD DAYS WILL COME FOR LOVE AND FORGETTING": \\ THE PLACE OF MEMORY IN MIRAMAR HOTEL BY EGOR \\ MARDONES
}

\section{MARÍA LUISA MARTÍNEZ M.*, PATRICIO TORRES C.**}

\section{RESUMEN}

Miramar Hotel de Egor Mardones evidencia la relación intertextual entre literatura, cine, música y vida. Las diferentes voces y presencias fantasmales que pueblan la heterotopía textual expresan el amor y el dolor que cobijan las paredes azules del espacio poético, casa de citas que deviene centro de tortura. El autor, un sobreviviente del horror evocado, registra y documenta los fragmentos dispersos de la memoria; desde el recuerdo de lo que allí se amó y se sufrió establece alianza con los lectores del texto, espectadores de la destrucción y de la muerte que gobiernan el espacio, y con las entidades espectrales que allí habitan. De esta manera, la escritura se constituye en resistencia contra la muerte y el olvido.

Palabras clave: Heterotopía, intertextualidad, memoria, resistencia, muerte.

\section{ABSTRACT}

Miramar Hotel by Egor Mardones shows the intertextual relationship between literature, films, music, and life. The various voices and phantasmagoric entities that popu-

* Artículo escrito dentro del marco del Proyecto $N^{\circ} 1110921$ del Fondo Nacional de Desarrollo Científico y Tecnológico: "Poesía chilena del siglo XX: esbozo de una historia de las relaciones entre poesía y muerte".

${ }_{* \star}$ Dra. en Literatura Latinoamericana. Profesora del Departamento de Español, Facultad de Humanidades y Arte, Universidad de Concepción. Concepción, Chile. Correo electrónico: marmartinez@udec.cl

${ }^{* * \star}$ Magíster en Literaturas Hispánicas. Estudiante del Programa de Doctorado en Literatura Latinoamericana Universidad de Concepción. Concepción, Chile. Correo electrónico: patrictorres@udec.cl 
late the textual heterotopia express the love and pain contained within the blue walls of the poetic space, a brothel that turns into a torture chamber. The writer, a survivor of the horror he evokes, records and transcribes the dispersed fragments of memory. From the remnants of what he loved and suffered, he establishes an alliance with the readers -spectators of the destruction and death that govern space- and with the spectral beings that inhabit the place, and thus, writing becomes resistance against death and oblivion.

Keywords: Heterotopia, intertextuality, memory, resistance, death.

Recibido: 14.03.14. Aceptado: 28.08.15.

"EN LA TRISTEZA INMENSA / DE MI DESOLACIÓN / LOS DUENDES DE MI MAL / ME VAN MORDIENDO EL CORAZÓN"

$1 \begin{aligned} & \text { IRAMAR HOTEL (2013) del tomecino Egor Mardones amplía y con- } \\ & \text { tinúa la serie de imágenes apocalípticas de una ciudad devastada, } \\ & \text { característica de la poesía chilena reciente. Esta última debe com- }\end{aligned}$ prenderse como aquélla producida después del golpe de Estado de 1973, acontecimiento que "afecta todos los planos de la vida nacional. En este contexto cultural, social, económico y político nuevo se inician productores que residen un espacio otro que difiere del que ocuparon los artistas chilenos precedentes" (Bianchi, 1987, pp. 172-173). Mardones se inscribe dentro de un grupo de escritores que se separa definitivamente de la continuidad y homogeneidad presentes en los poetas del sesenta (que explicitaban su deseo de proseguir la gran tradición de la poesía chilena, intención de la que discrepan los poetas posteriores), y que se sitúa en un plano marginal respecto de los grandes poderes editoriales, académicos y económicos que suministra el centralismo. Sin embargo, este aislamiento, aparentemente desventajoso, "puede ir derivando en mayor independencia en la creatividad y en desarrollos paralelos" (Bianchi, 1995, p. 12). La obra de Mardones se produce desde los márgenes, desde la provincia, y prosigue la reflexión poética sobre una ciudad "donde las callejuelas de aguas estancadas son el 'único cielo' al que puede aspirarse” (Triviños, 1989, p. 75).

Miramar Hotel, de compleja composición, se abre con un film countdown y luego un texto de Nelly Richard que advierte sobre la función del destinatario, uno imaginado, deseado, y que "viene a ser el resultado de lo que / los textos construyen como su posibilidad de lectura" (2013, p. 11) ${ }^{1}$. Este

\footnotetext{
${ }^{1}$ Todas las citas de Miramar Hotel llevarán sólo número de páginas. Ver referencias bibliográficas.
} 
aviso luminoso es fundamental para desentrañar la disposición exigida por el autor para abordar el libro/película, que se divide en tres planos fundamentales: el primero lo constituye el cielorraso, que corresponde al texto propiamente tal y que, como se indica, es el (pre)texto o la excusa para los dos siguientes planos; el segundo corresponde a las paredes azules del Miramar hotel, la banda de imagen entendida como "imaginería sentimental de segunda" (17), que quiebra la visión textual al incorporar referentes gráficos (elementos visuales como fotografías, fragmentos de cómics y cintas cinematográficas); finalmente, el tercer plano se refiere a la banda sonora del texto y corresponde al tango "Desvelo" de Cadícamo y Bonessi, que acompaña gran parte de la lectura. Estos tres planos, el textual, el gráfico y el sonoro, obligan a leer, mirar y escuchar la obra de Mardones en un sentido que se complejiza aún más al alternar la mentira de la ficción textual con la verdad de aquello que se ve y que se oye, y que el texto se empeña en validar como real:

Y NO ERAN ARTIFICIALES, no, los fuegos que encendían el cuerpo

Y NO ERAN DOBLES, no, no éramos, los amantes en acción

del delito y el amanecer

en el cuartito azul del miramar hotel

PORQUE TAMPOCO ERAN DE LA BANDA sonora las olas que ensordecían al reventar contra las rocas

NI LITERARIAS LAS CONVERSACIONES sostenidas hasta los delirios más underground de por aquí: tú NI TAMPOCO PURA UTILERÍA EL MURO de la fábrica abandonada donde ahora brilla por su ausencia un hermoso mural NI FALSAS LAS IMÁGENES PROYECTADAS al rojo muerto sobre las paredes de tu clandestina imaginación (51).

Miramar Hotel, una suerte de casa de citas, caza de citas o casa de putas fantasmagórica, se estructura, además, en tres partes (Fachada, Fragmentos y Subterráneo) que registran diferentes voces y tiempos en forma documental. Las paredes azules del hotel albergan parejas que intentan leer y descifrar, como el mismo lector, los referentes que pueblan la imaginación marginal ${ }^{2}$ y desbordada de las presencias que la

\footnotetext{
${ }^{2}$ Soledad Bianchi se ha referido en “¿Qué dicen los prefijos?” a la influencia que la generación beat y la cultura norteamericana han ejercido sobre las diversas agrupaciones poéticas marginales hacia el final de la década del sesenta y destaca los diálogos intertextuales que la literatura establece con los medios de comunicación masivos, de evidente ascendencia en la escritura de Mardones.
}

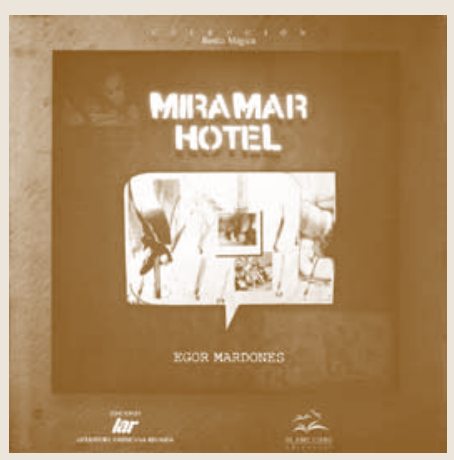


habitan ${ }^{3}$. Así, Thomas de Quincey, Alain Robbe-Grillet, Brian de Palma, William Burroughs, Miguel Littin, Juan Domingo Dávila, Liliana Cavani, Woody Allen, Julie Newmar, Andy Warhol, Susan Sontag, Alfonso Alcalde, Paul Delvaux, William Blake, el marqués de Sade, Groucho Marx, Andrea Pazienza, Saint-John Perse, Marlon Brando, María Schneider, Anthony Burgess, entre otros, filman, escriben, pintan y pueblan un espacio heterotópico, de acuerdo a la concepción otorgada por Foucault ${ }^{4}$, que es testigo del amor y del horror de quienes allí convergen. La voz del poeta se mezcla con voces que la han precedido o que quizás nunca han existido, pero que pueden oírse a partir de la banda sonora del libro ${ }^{5}$, que recoge las voces que el poeta intenta reconstruir.

El presente resulta tan fantasmagórico como el pasado que se evoca, pero la memoria de las historias menores que componen el universo del hotel, ahora reducido a cenizas, cuestiona la irrealidad del recuerdo o del sueño: "En el triste cuarto de un hotelucho, David Banner exprime su torturado cerebro... ¡Ocurrió de nuevo! ¡Yo no pude controlarlo! Tengo que recordarlo... ¡Antes que olvide todo!” (91). La memoria expresa un tejido de tiempos contradictorios, "las texturas temporales que no sólo son las que arman el discurso de la memoria y de la historia, sino que muestran de qué sustancia temporal heterogénea están tejidos los hechos" (Sarlo, 2012, p. 81), y aúna en su interior diferentes espacios y tiempos que borran las fronteras entre sueño y realidad.

Miramar Hotel dialoga con Taxi driver, el libro de Mardones que narra el trayecto marginal de un solitario taxista que "intenta escaparse de sí mismo y de su entorno, aun sabiendo que en 'Night Citi', los proyectos, los cambios, no están permitidos y que la 'Avenida Utopía Forever' es sólo eso, apenas un nombre (Bianchi, 2009, pp. 12-13), y que traza un recorrido

\footnotetext{
${ }^{3}$ Juan Zapata sitúa la obra de Mardones, una escritura desterritorializada que poetiza espacios marginales, dentro del contexto de la sociedad postindustrial y de la cultura postmoderna, en las que unas nuevas sensibilidad y estética han desaparecido y han dado lugar a una hiperrealidad, "donde la noción de arte como categoría aparte se ha desvanecido" (Zapata, 1999, p. 14).

${ }^{4}$ Las heterotopías, según lo propone Foucault en El cuerpo. Las heterotopías, corresponden a utopías situadas y se establecen a partir de criterios establecidos por cada grupo humano que las conforma: el primer criterio define los lugares utópicos y los sitúa en un lugar determinado; el segundo criterio señala que las heterotopías pueden ser modificadas en el tiempo; el tercer y cuarto criterio indican la naturaleza crónica de algunas heterotopías (las que, por lo tanto, se realizan en un tiempo concreto), mientras que otras poseen un carácter eternizante. Finalmente, el quinto criterio plantea que las heterotopías son zonas de aislamiento ligadas a un sistema de apertura y cierre que regula la entrada a ellas.

${ }^{5}$ Esta banda sonora, como también la de Taxi driver (2009), "musicaliza los recorridos por la periferia de la devastada 'citi', la que posee guiños que la conectan con la realidad y múltiples ventanas utópicas” (González y Torres, 2013, s/nº).
} 
que va "rodando por la Costanera de los desesperados" (Mardones, 2009, p. 66) para llevar a las parejas urgentes que encuentra a su paso. En ambos textos es posible observar el predominio de la violencia; ésta, sin embargo, no parece alcanzar al lector en el caso del texto que dialoga con la película de Scorsese. La claustrofóbica imagen del hotel, en cambio, "se constituye en un espacio ominoso en el que un personaje de comic dispara un tiro a un sujeto ('tú te lo has querido') que el reverso de la página, coincidente con el final del texto, identifica con el 'asqueroso lector de basura y porquería, es decir con nosotros, los lectores. Acto de exorcismo que asume la violencia dominante, pero para consumirla en el ejercicio (im)productivo de la escritura poética" (Triviños, 1989, p. 99). La ciudad húmeda, indómita y deteriorada ejerce presión en la producción poética penquista, la que se materializa en un espacio degradado cubierto de cicatrices que han dejado diferentes desastres. Es la ciudad real, en términos de Beatriz Sarlo, la que ejerce presión sobre la ciudad escrita, imponiendo su fuerza simbólica sobre la ficción, a pesar de su diferente naturaleza semiótica: "Escribir la ciudad, dibujar la ciudad, pertenecen al círculo de la figuración, de la alegoría o de la representación. La ciudad real, en cambio, es construcción, decadencia, renovación, y, sobre todo, demolición" (Sarlo, 2009, p. 145). Los poetas penquistas describen Concepción como una ciudad en un proceso constante de trasformación o [re]construcción que conjuga lo urbano y lo rural, lo clásico y lo moderno, la barbarie y la civilización. De esta manera, reflexionar respecto de la escritura de Mardones implica "hacerse cargo de algún modo de la fisonomía degradada, perversa, casi maldita con que el espacio penquista emerge en la conciencia de sus poetas. Lugar del deshecho, lugar de los discursos antiutópicos, lugar en que el amor sólo puede expresarse bajo la forma del odio, Concepción es el espacio húmedo y macabro en que la vida es una peregrinación del prostíbulo al Cementerio" (Alonso et al., 1989, p. 16). La poesía de Mardones es urbana y apocalíptica; los espacios aparecen siempre devastados debido a un hecho traumático que acaece o que ha acaecido. Estos contextos distópicos, o más bien heterotópicos, imprimen un rasgo claustrofóbico a su escritura que alcanza al lector, espectador, habitante o pasajero, a quien sólo le queda testimoniar el dolor.

\section{"DE LOS ESPEJOS TURBIOS / DE MI MELANCOLÍA / TODOS NUESTROS AMORES / SURGEN DE AQUELLOS DÍAS”}

La primera parte del texto, Fachada, comienza con algunas imágenes y textos eróticos que permiten creer en la posibilidad de la esperanza. Los juegos 
léxicos, que abundan en el libro, abordan el doble sentido propio de una lengua marginal y exacerban la dualidad del amor vinculado a la muerte, como sucede en "tirando a perder": "ESTAMOS TIRANDO A MORIR en el cuartito azul del miramar hotel / la cabeza de playa se nos va a más de 45 rpm: AQUÍ SE HA FUMADO / Y BEBIDO EN EXCESO y en tales condiciones se ha leído a Blake: / antes asesina a un niño en su cuna que nutras deseos que no / ejecutes" (41). Este lugar común transgresivo, poblado de voces e imágenes heterogéneas, sigue la lógica de la violencia de la colaboración en el plano textual, gráfico y sonoro, y se constituye, paradojalmente, en un tiempo anacrónico: "Varios autores aparecen dentro del cuadro compartiendo su superficie y proyectando en ella imágenes presentes y pasadas, propias y ajenas" (49). El lector también participa de esta violencia que el texto exige y traza un recorrido por cambios de rollo o sábanas que despliegan diferentes tiempos y voces. El poeta pulsa play en "madrugada" y recuerda que entonces "hacemos el amor en el cuartito azul / del miramar hotel / HABITADO AHORA SÓLO POR FANTASMAS” (25). La lectura o el trayecto de la imaginación se precipita hacia el componente pornográfico en "carne de mujer" y se contagia hemofílicamente del halo siniestro en "vamp", en el que Klaus Kinski aparece "AFILANDO LOS COLMILlOS (y el sexo) I para echársete al cuello (Y ENCIMA) de un momento / A OTRO” (33). Luego, el elemento distópico va ocupando el texto; las palabras tachadas en "decreto" hablan de una interdicción que se cierne como "ROJO APOCALIPSIS NOW" (37) en torno al cielorraso y sobre las sábanas del hotel: “/ santo sudario / palabras de la cintura parabajo / cuerpos en movimiento / sobre las que proyectamos / nuestras negras y hoy PROHIBIDAS IMÁGENES deereto exento 4559 / (...) que esperamos algún día de insurrección / lapsus resurrección / sean en tecnicolor" (37). Los amantes experimentan el amor como pornografía y ésta, como señala Manfred Jürgensen ${ }^{6}$, traza una anticipación sensual de la muerte. La sexualidad pornográfica se representa como muerte experimentable y, desde una perspectiva teológica, su tema es la resurrección del cuerpo. El lector juega especular e intertextualmente con este motivo, una constante en el arte erótico y pornográfico, y asume la perspectiva del indiscreto voyeurista de "Doble de cuerpo" en el poema "de palma". El voyeurismo es una constante en la obra de Mardones, "sin embargo, aquí es la materia misma" (39) y el escenario espiado es el interior del hotel. La interpelación al lector para que participe de los códigos de

${ }^{6}$ Jürgensen se refiere a las características de la pornografía literaria en su texto Beschwörung und Erlösung (1985). 
lectura sugeridos se expresa en "fotos porno" y en la banda de imagen que cubre las paredes del hotel. En una de ellas, el fotograma de Julie Newmar y Woody Allen sorprende a camarógrafos y fotógrafos que captan la toma, el autor del texto la imprime e invita al lector a participar de la autorreferencialidad $^{7}$ del fragmento. El efecto excitante del texto y de la imagen es tematizado al interior del poema y le proporciona al lector un modelo a seguir. De esta manera, la lectura es también un acto de voyeurismo que transgrede la "ciudadela de la intimidad, el recinto nocturno donde reunir los elementos fragmentados o fatigados de nuestra conciencia" (Steiner, 2003, p. 96).

La muerte y sus figuraciones habitan todos los cuartos y muros del Miramar Hotel. Todos quienes se aventuran a ingresar en él expresan alguna forma de muerte y ésta se integra al espacio textual. Miramar Hotel se construye arquitectónicamente como una heterotopía que difumina los ya borrosos límites entre realidad y ficción, y las presencias que pueblan el hotel establecen alianza con las otras entidades involucradas en su producción y lectura. La ficcionalidad trasciende las fronteras del texto y faculta la posibilidad de morar el espacio evocado que rescata la memoria y que resiste la irrealidad que todo texto literario alberga en su interior: "No se vive en un espacio neutro y blanco; no se vive, no se muere, no se ama en el rectángulo de una hoja de papel. Se vive, se muere, se ama en un espacio cuadriculado, recortado, abigarrado, con zonas claras y zonas oscuras, diferencias de niveles, escalones, huecos, protuberancias, regiones duras y otras desmenuzables, penetrables, porosas" (Foucault, 2010, p. 20). El autor y el lector penetran al interior del texto, pululan en los corredores, deambulan insomnes en madrugadas frente al mar y aman entre las blancas (ahora manchadas de rojo) sábanas del hotel. Las paredes azules del espacio y del texto cobijan personajes rescatados por la memoria del autor, fantasmal testigo de la muerte que parece alcanzarlo, y se materializan en la imaginación del lector, quien también deviene un espectral sobreviviente del texto y de la muerte. La heterotopía del espacio poetizado surge "en lo imaginario en el punto donde los muertos ya muertos y los moribundos que van a estar muertos se tornan indistintos" (Ricoeur, 2008, p. 46). La naturaleza delirante del texto faculta la posibilidad de devenir otros en el espacio evocado, a través de la escritura testimonial de lo que allí sucedió y a través

\footnotetext{
${ }^{7}$ Carolina Fischer señala en Gärten der Lust (1997) que la autorreferencialidad es una de las características de la literatura excitante. El texto despierta el deseo erótico en el lector y, a través de una sucesión de escenas especulares, lo lleva a imitarlas.
} 
de la lectura del dolor inscrito en los muros del lugar, y constituye una cadena escritural que involucra la ficción, la realidad del autor y también la del lector imaginado: "Los personajes de las ciudades [...] de Mardones están igualmente imantados por los muros en los cuales la multitud escribe clandestinamente su resistencia. Escritura en la página del muro, muerte y dolor son los motivos poéticos predominantes" (Triviños, 1989, p. 95). Así, el lector también ejerce una resistencia al poder social, político y escritural que Miramar Hotel denuncia y no deviene sólo otro espectador más de las imágenes que éste proyecta, sino que también ingresa a la marginalidad que el topos uranos ostenta:

La pálida LA GRAN CABRONA GRAN nos varó con malas artes en este solitario rotativo del miramar hotel donde tanto azul desperdiciado NOS HACE PASARNOS PELÍCULAS DE MORBOSA CALIDAD \& PEOR VIDEO TAPE porque como es bien ignorado el topos uranos es un sitio en el que fácilmente PODEMOS COMETER DELITOS volvernos locos, vivirnos el off-off cagados de la risa

O ALGO ASÍ (73).

\section{“Y EN ESTE DRAMA MÍO / YO ME HUNDO SIN PIEDAD”}

La segunda parte del texto, Fragmentos, escarba en historias particulares que registran la marginalidad y el sufrimiento, como sucede en "la plagiaria”. El pasado feliz del encuentro amoroso se transforma en "imágenes dizque retro" que anticipan los "malos días para el amor y el olvido / impulsados por despellejadores vientos de pasión y desgracia" y que, de acuerdo a la naturaleza sonora del texto, se oye en "WATTS DE POTENCIA Y A TODO STEREO EN TU CUARTO AZUL / DE PORQUERÍA" (57). Las paredes que rodean a los sujetos están impregnadas de dolor y violencia, y remiten al contexto de la Dictadura Militar. El hotel se configura así en centro de tortura y, a la vez, en espacio de confesión y lamentos de "las sombras [que] pueblan y DESPUEBLAN las dependencias/ del miramar hotel” (29). El horror político de ese plazo de nuestra historia es documentado por ojos que registran el dolor. El amor, las drogas y la imaginación pornográfica son bombardeadas por el Enola gay en "UN IMPREVISTO / hiroshima mon amour y nagasaki" (57) que devora la realidad del hotel, pero no las imágenes que él proyecta. La muerte se trasunta en la soledad del poeta, sobreviviente y espectador del escenario apocalíptico que despliega el poema "balas locas": 
Sin embargo UNA MADRUGADA LAS BALAS

alcanzaron el topos uranus del Miramar hotel

atravesando LA PARED Y UNA IMAGEN de Dávila

sobre no sé qué hotel room que por horas y horas

observamos INCRÉDULOS ENTRE EL HUMO Y EL HUECO

que marcamos con tizas de colores para regocijo

de (nuestros) OJOS Y DEL VIDEO TAPE (63).

El poeta es un sobreviviente que testimonia la muerte desde la contemplación del espanto que rodea su mundo y sus referentes, y "el testigo, en la palabra testimonial, siempre y primariamente es una palabra sobrevivida; además la muerte es insustituible, nadie más que el muriente puede testimoniar sobre ella" (Derrida y Ferraris, 2009, p. 110). La voz poética asume la función de registrar otras voces; el discurso confesional presente en algunos textos señala una queja, una denuncia social y política, y también la esperanza de la redención, "de una revelación de la vida, de que se disuelvan los [...] horrores, de que la vida, al descubrir algo más allá de ella, encuentre al fin su figura y deje de ser pesadilla" (Zambrano, 2004, p. 35). Adriana, de 52 años, y Alejandro, de 54, expresan la desesperación ante el horror en "me llevaron al interrogatorio..." y en "siento como si fuera hoy", respectivamente. Las torturas de las que fueron objeto recuerdan otras historias semejantes que tuvieron un desenlace más trágico aún, porque sus víctimas están muertas. Su condición de sobrevivientes faculta su mediación con el mundo de los vivos a partir de su posición de protagonistas y testigos de la muerte:
Me llevaron al interrogatorio, los gritos se acercaron y había música, recuerdo haber escuchado 'Capricho italiano', de Tchaikovsky. Un hombre al que le decían 'El fiscal' o 'Doctor' era el que interrogaba. Me pusieron corriente, cuando terminaron seguí sintiendo los gritos de los otros torturados (65).

El poeta se contagia de estas voces disidentes a partir de la confesión, y sus quejas y plañidos "nos llegan en el mismo tiempo en que fueron pronunciados; es como si los oyéramos; suenan a viva voz" (Zambrano, 2004, p. 26). El dolor impone la necesidad ética de recordar y de escribir la memoria de un país asolado por la violencia y sus múltiples figuraciones. La cita de Variaciones sobre el tema del amor y de la muerte de Alfonso Alcalde 
expresa las ansias de redención para "AQUÉLLOS / que disecaron sus solitarias / porciones de tristeza / a lágrima viva y luego ultrajaron / el llanto / en profundos cuartos / azules borrosos amarillentos / de hoteles de tercera clase" (71) y "AQUÉLLOS / QUE EXTERMINADOS de bruces / marchitos para siempre / hirvieron en su propio / cristalino y transpirado caldo glorioso / TODOS SEAN PERDONADOS (71). Este anhelo encuentra respuesta al final del libro, cuando se sugiere la amnistía para los sueños del poeta y para quienes ingresan al texto y viven el dolor que el espacio traza en líneas que buscan un destino ${ }^{8}$.

M.L.R., 17 años, reo por homicidio con lesiones en "y ahora qué querís hacer", vincula el amor y la muerte en un relato que reúne la contradictoria relación hecha de espanto y placer, y sus pocas pertenencias (diferentes armas blancas y un recorte del periódico con el aviso de un motel al que desea llevar a su mujer cuando esté libre) expresan la precariedad de su vida y de sus deseos. La marginalidad del mundo poetizado, los consumidores de drogas de bajo presupuesto y los personajes que transitan por las madrugadas de una ciudad innominada establecen un diálogo poético "de muerte y renacimiento, de desintegración y redescubrimiento del mundo, de descenso y ascenso del infierno, de pérdida y recuperación de la palabra, de desacralización y resacralización [...] de héroes derrotados o agotados que ya no esperan nada y mujeres que esperan con ardiente (im)paciencia" (Triviños, 1989, p. 77). Las vidas que se arrastran por trayectos que no ofrecen salidas ni vías de escape recuerdan la intemperie de la noche americana y/o penquista de Taxi driver: "Sólo yo sigo llevando en mi taxi a Partealguna / a pasajeros que en su perra vida han salido de Nada / que jamás se han movido o moverán ya para siempre / de Aquí/" (Mardones, 2009 , p. 76). El lenguaje de las orillas surge desde el desperdicio de vidas que se consumen en la apatía; el poeta faculta el testimonio de estas voces a través de la adopción de diferentes máscaras que le permiten devenir otro y disfrazarse por medio de la ficcionalización. De esta manera, la pluralidad de citas sirve como recurso que permite sobrevivir en un mundo hostil y

\footnotetext{
${ }^{8}$ Es necesario destacar que las diferencias que el grupo de escritores posteriores a la década del sesenta expresa respecto de sus antecesores son fundamentalmente estéticas; ambos grupos establecen un vínculo ético en relación a la percepción del contexto sociopolítico nacional y a la producción poética que se desprende de ella, hecho que los lleva a postular una posición escritural que se plantea en términos críticos respecto del dolor, del abuso, de la censura y de la muerte que habita nuestra memoria.
} 
peligroso, porque no sólo la noche representada y textualizada está llena de fantasmas, sino que el país entero parece estar poblado de presencias que buscan una salida, una ventana utópica a la violencia que domina el espacio textual. La fuga de estos espacios distópicos, regidos por un poder avasallador, se encuentra en los mensajes escritos en los muros, en las paredes / páginas del texto, el que como "toda obra de arte, toda filosofía central, ha poseído y posee siempre una ventana utópica ante la que se extiende un paisaje a constituir" (s/a, 1993, p. 6). La música, el cine y la literatura, manifestaciones que dialogan entre sí a lo largo del texto, se ofrecen como líneas de fuga necesarias y buscadas incansablemente durante las noches sin fin. En algunas ocasiones, la adopción de la máscara de la muerte contagia la escritura y, de esta forma, imprime sobre el texto "la signatura de memorias de ultratumba" (Derrida, 2008, p. 40). El poeta es un muerto vivo, un fantasma más de los muchos que rondan por el hotel destruido. En otros momentos, el autor se contagia y puebla de entidades tan espectrales y underground como la muerte, y con ellas constituye una manada. Mary, 18 años, reina de la noche, establece alianza con el poeta, uno de los gatos descarriados de "estuve meses como un mueble". El testimonio de esa vida desamparada permite la ficcionalización y "la autoinmolación o desaparición de todo sujeto en cuanto centro o fundamento del discurso poético" (Giordano, 1987, p. 340). El poeta establece un bloque en devenir que hace suya la falta de esperanza y expectativas, la monotonía de los días, los desvelos, las madrugadas encendidas, las drogas: "Eso y también a la mañana fumando chilombiana / moderatto. / Eso y también a la tarde chupando pisco / in excess. / Eso y también a la noche culeando como loca / La Perricholi. / Créeme, te soy sincera: no tenía en la vida otra mierda / QUE HACER" (81). La fiebre y el delirio hacen presa de la alucinada imaginación pornográfica, inquieta y al mismo tiempo inmóvil de los habitantes del hotel en "insomnio". La fragmentaria y caleidoscópica mirada de aquéllos a quienes la noche y la vida consumen en un tiempo ucrónico, despojado de coordenadas que permitan dar cuenta del paso de los días, expresa el influjo que la ciudad ejerce sobre ellos. Mardones textualiza el desamparo de la noche penquista en Taxi driver, "una ciudad donde no es posible trazar un futuro, situación que lleva a los sujetos a adentrarse en un universo personal alucinado que bordea con la locura" (Sepúlveda, 2010, p. 112), y registra el mismo abandono, la misma orfandad e indigencia en Miramar hotel. Jaime Vera, cesante, soltero, sin profesión, expone la desvalidez de su vida en "de la paja como una de las bellas artes": "Perdón..., perdónenme, 
pero no puedo crear nada. / Mi intelecto / atacado por la televisión, mi cerebro / destruido por el alcohol, la / nicotina pegada a mis / pulmones me destruyeron y ahora soy incapaz / de / eyacular arte. Soy como semen pegado a las sábanas / después / de una masturbación. Soy algo que nunca / generará VIDA" (85). El autor del texto asume este discurso y poetiza la improductividad que acusa esta máscara discursiva. Los cuerpos, y las miradas que de ellos emanan, comprenden que se acerca el fin y que la muerte ejerce su poder totalizador: ENCENDIDOS DE AMOR en el Miramar hotel / vemos asaz desesperados cómo el THE END empieza / a invadir, terrible, LAS PERSEGUIDAS PANTALLAS de nuestra / subversiva imaginación de cine periférico y porno-GRÁFICO" (87). Nuevamente se hace visible la relación entre placer y violencia, ya que el deseo de recomenzar se apodera del cielorraso. El anhelado rewind anuncia la circularidad del sueño textual, la vuelta al origen. La anacronía evidencia la imposibilidad de ordenar los fragmentos dispersos de la memoria, porque la naturaleza violenta de los recuerdos evoca la tortura social, política y emocional que las presencias fantasmales del hotel han padecido y padecen. El sufrimiento ha abolido las nociones temporales, porque "el tiempo es destruido por la tortura. El dolor es una presencia absoluta, permanente. Ocupa el campo entero de la conciencia" (Sofsky, 2006, p. 98). Después de la tortura, del dolor, de las quejas, de los deseos insatisfechos y de las fatigas que pueblan la segunda parte del texto, surgen las ansias de reconstruir el pasado. El tiempo se impone tratando de establecer un orden progresivo, pero el texto resiste esa marca de poder $y$, a través de sus múltiples transgresiones, se precipita hacia la complementariedad entre horror y placer, porque "el orgasmo sexual y la violencia desatada siguen cursos paralelos" (Sofsky, 2006, p. 56). El poema "orgasmo múltiple" es el único fin posible para la pornográfica imaginación de quien testimonia lo sucedido y en él convergen las voces de Woody Allen, Andrea Pazienza, el marqués de Sade y Groucho Marx. Estas cuatro citas resumen la intención poética del autor e intentan explicar la distancia entre "el proyecto / que yo tenía en la cabeza y el resultado final!" (89), la naturaleza imperfecta del texto que se explicita en el "podría hacerlo mejor, claro, / pero tengo asuntos pendientes que me importan / mucho más" (89) y la pequeña muerte de la escritura, que, como la libertina de Sade, "acaba [...] antes de que se la toque" (89). El rasgo risueño al final de "orgasmo múltiple" lo aporta Groucho Marx, quien se resiste a la despedida y la alarga jocosamente. 
La tercera parte del libro, Subterráneo, concluye la arquitectónica escritura de Miramar Hotel. La cita de Saint-John Perse grafica lo que el texto ha evidenciado con anterioridad y se refiere al "gran principio de violencia / [que] regía nuestras costumbres" (95). La violencia de la colaboración se hace extensiva al autor y a los lectores del texto, y anteceden a la "pantalla en blanco (desechable)" que constituyen los créditos finales del texto / película de Mardones. Discursos de diferentes disciplinas artísticas (literatura, cine, música) convergen con personajes reales, ficticios y con distintos registros de habla. La realidad y la ficción terminan por integrarse en un polifónico y caótico cierre, y confunde el cielorraso con las bandas de imagen y sonora del texto. Las diferentes disposiciones de la cámara (primer plano, picado, contrapicado, plano general, travelling, cámara lenta, fundido y cámara americana) coexisten con el lenguaje literario y el coloquial, con actores y presencias del hotel, y con los créditos de imagen y sonido, en un desesperado intento por testimoniar el pasado. El carácter desechable del texto expresa la arbitraria elección de estos enunciados en desmedro de otros que también podrían componer el final abierto que el libro postula. Aquello que se amó, lo que se vivió, lo que se vio, lo que se imaginó, lo que efectivamente sucedió y lo que se anheló puede ser destruido por el presente que se impone, pero que el texto resiste. El dolor y la desesperanza patentes en la violencia reinante de algunos enunciados, "de un puntapié le volaron los dientes dios tarda y olvida" (97), se mezcla con el erotismo de otros que combaten la muerte y el sufrimiento desde la marginal y alucinada imaginación de "cuerpos ardientes en la ventana" (97). La imaginación pornográfica desafía a la muerte y materializa la persistencia de elementos heterotópicos en el texto. La insurrección que el erotismo postula es una forma de resistencia escritural a una realidad opresiva y debe comprenderse como el plano utópico del libro, que conduce necesariamente a la muerte. El azul de las paredes (el color de la imaginación) se tiñe de rojo (el color de la violencia que se impone) y alcanza el desborde de los sueños plasmados en la imagen de "marlon brando enmantequillando contra natura a la maría schneider" (97), y reconocen que ésta, como "toda búsqueda realmente obscena se encamina hacia las satisfacciones de la muerte, que suceden y 
sobrepasan a las del eros" (Sontag, 1997, p. 92). La ilusión de libertad del "mueva las caderas más a fondo mi gatofritz" (97) se quiebra con la CENSURA, con mayúsculas y negrita, que despojan al autor / personaje / protagonista / testigo del sueño presente en el "así que poeta el huevón detenidos y confesos ante el todopoderoso" (97) y "UNA VOZ EN OFF AAAGGGHHH FINAL ABIERTO" (97) que oscurece la pantalla.

La muerte anticipada alcanza la escritura y la pluralidad de voces presentes es acallada en Miramar Hotel. El texto o sábana "pantalla en blanco (copia nueva)" retoma el plano general, pero ahora desde el silencio poético: en primer lugar, el cielorraso, el plano textual del poema, se oscurece con la imagen de la máquina de escribir en llamas (imposibilidad de escritura); en segundo lugar, la banda de imagen es destruida por los desconocidos de siempre (aludiendo a la película de Mario Monicelli); en tercer lugar, la banda de sonido y todo lo que proyecta "tu morbosa y espantable imaginación" (99) son amordazados con tela adhesiva en gesto de censura. Sin embargo, el texto prosigue y la violencia que domina todo el libro surge nuevamente y se extiende hacia el lector; el autor adopta una nueva máscara que le permite agredir y luego disparar al lector del texto, porque éste así lo ha querido. La amnistía que el texto proclama absuelve a su autor de todo delito, porque el lector también es responsable de la violencia imperante y porque todos quienes integran, observan, escuchan, pintan o filman la heterotopía textual son responsables y resulta "IMPOSIBLE DAR CON LOS CULPABLES, IMPOSIBLE / DAR CON LOS CULPABLES. IMPOSIBLE” (99).

Las últimas páginas de Miramar Hotel sintetizan la naturaleza intertextual del poema y grafican la resolución del autor / editor / director de publicar / rodar / presentar el libro / película: "FINAL APROBADO CON OBJECIONES. / TRUCAR COMO ES DEBIDO. NO IMPORTA / EDITAR BANDA DE SONIDO. / TIRAR PRIMERA COPIA. / EN FIN..." (105). El continuará final establece un diálogo con las cintas cinematográficas que prometen segundas partes, pero que en Miramar Hotel debe comprenderse como explicitación de un final abierto que evidencia la continuidad de los textos circulares que se relacionan en la obra de Mardones (la literatura, el cine, la música y la vida), porque en eso radica la intertextualidad que sus libros postulan, en "la imposibilidad de vivir fuera del texto infinito -no importa que ese texto sea Proust, o el diario, o la pantalla televisiva: el libro hace el sentido, el sentido hace la vida..." (Barthes, 1993, p. 59). La insurrección de la memoria continuará en un trazo real e imaginado en "estos CLANDESTINOS PAPELES DE AMOR MARCA REGISTRADA" (79) que resisten la muerte y el olvido. 


\section{REFERENCIAS}

Alonso, M. N.; Mestre, J. C.; Rodríguez, M. y Triviños, G. (1989). "La diáspora”. En Las plumas del colibrí: Quince años de poesía en Concepción (1973-1988) (pp. 11-52). Santiago: INPRODE.

S/a. (1993). "Editorial". En Anthropos, No 146-147, julio-agosto.

Barthes, R. (1993). El placer del texto. Madrid: Siglo Veintiuno Editores.

Bianchi, S. (1987). "La imagen de la ciudad en la poesía chilena reciente". Revista Chilena de Literatura, 30, 171-187.

Bianchi, S. (1995). “¿Qué dicen los prefijos?”. En Bianchi, S., La memoria: modelo para armar. Grupos literarios de la década del sesenta en Chile. Entrevistas (pp. 9-17). Santiago: Ediciones de la Dirección de Bibliotecas, Archivos y Museos.

Bianchi, S. (2009). “Triste, desalado y sólo” (Prólogo). En Mardones, E., Taxi driver (pp. 9-18). Tomé: Ediciones Al Aire Libro.

Derrida, J. (2008). Memorias para Paul de Man. Barcelona: Editorial Gedisa.

Derrida, J. y Ferraris, M. (2009). El gusto del secreto. Buenos Aires-Madrid: Amorrortu Editores.

Fischer, C. (1997). Gärten der Lust. Stuttgart - Weimar: J. B. Metzler Verlag.

Foucault, M. (2010). El cuerpo utópico. Las heterotopías. Buenos Aires: Nueva Visión.

Giordano, J. (1987). Dioses, antidioses. Ensayos críticos sobre poesía hispanoamericana. Concepción: Ediciones Lar.

González, C. y Torres, P. (2013). "El viaje es el karma, el viaje es el poema: desplazamiento/escritura en la distópica ciudad de Taxi driver de Egor Mardones”. En: http://postgradoliteratura.udec.cl/wp-content/uploads/2013/08/ art\%C3\%ADculo-taxi-driver-16-de-mayo.pdf

Jürgensen, M. (1985). Beschwörung und Erlösung. Bern - Frankfurt am Main New York: Peter Lang Verlag.

Mardones, E. (2009). Taxi driver. Tomé: Ediciones Al Aire Libro. . (2013). Miramar Hotel. Tomé: Ediciones Al Aire Libro.

Ricoeur, P. (2008). Vivo hasta la muerte. Buenos Aires: Fondo de Cultura Económica.

Sarlo, B. (2009). La ciudad vista. Buenos Aires: Siglo Veintiuno Editores, S.A. 2012. Tiempo pasado. Cultura de la memoria y giro subjetivo. Una discusión. Buenos Aires: Siglo Veintiuno Editores.

Sepúlveda, M. (2010). "Concepción recobrado en la poesía chilena”. Taller de Letras, 47, 105-115.

Sofsky, W. (2006). Tratado sobre la violencia. Madrid: Abada Editores.

Sontag, S. (1997). "La imaginación pornográfica”. En Sontag, S. Estilos radicales (pp. 57-109). Madrid: Editorial Santillana.

Steiner, G. (2003). Lenguaje y silencio. España: Gedisa.

Triviños, G. (1989). "El regreso”. En Alonso, M. N.; Mestre, J. C.; Rodríguez, M. 
y Triviños, G., Las plumas del colibrí: Quince años de poesía en Concepción (1973-1988) (pp. 53-113). Santiago: INPRODE.

Zambrano, M. (2004). La confesión: género literario. España: Ediciones Siruela. Zapata, J. (1999). "Prólogo" (pp. 7-16). En 1999, Concepción. Concepción: Malaface. 